\title{
気管支洗浄液のテロメラーゼ活性測定の 肺癌診断における有用性
}

\author{
The Utility of Telomerase Activity in Bronchial Lavage \\ for the Diagnosis of Lung Cancer
}

出口博之・四/宮成祥 $*$ ·尾関雄一・佐藤光春

桑原元尚・原口秀司・尾形利郎**・田中 勧

\begin{abstract}
要旨: 肺癌 33例, 非肺癌 15例の気管支洗浄液のテロメラーゼ活性をnon-RI法により測定し, 肺癌の補助診断法としての有用性について検討した。肺癌症例の陽性率は $78.8 \%$ で，非 肺癌の $26.7 \%$ に比べ有意に高率であった.組織型別では扁平上皮癌 $88.9 \%$, 腺癌 $81.3 \%$, 大細胞癌 $50 \%$ ，小細胞癌 $66.7 \%$ であった。細胞診との比較ではclass II で $36.4 \%$, class III で33.3\%, class IV, Vで91.3\%の陽性率であり，細胞診のclassの高いものほど，テ ロメラーゼ活性の陽性率も高かった(Spearman : $\mathrm{p}=0.0001)$. class II と診断された中 で最終診断が肺癌であった症例は $57.1 \%$ 陽性率であり, 非肺癌の $26.7 \%$ に比べ高い傾 向にあった，細胞診で確診がつかない症例でもテロメラーゼ活性が高い場合には肺癌で ある可能性が高く, 気管支洗浄液のテロメラーゼ活性測定は肺癌の補助診断法として有 用であると考えられた。
\end{abstract}

〔肺癌 $38(7): 815 \sim 823,1998 〕$

Key words : Telomerase, TRAP assay, Bronchial lavage, Lung cancer

\section{はじめに}

悪性腫瘍細胞の特性として無限増殖能(不死化), 浸潤能, 転移能などがある。このうち無限増殖 能を保つメカニズムのひとつとして染色体の末 端構造 (テロメア)を伸展させるテロメラーゼ ${ }^{1)}$

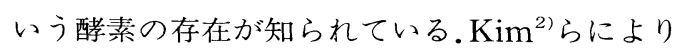
報告されたTelomeric repeat amplification protocol(TRAP法)によりPCRを用いてテロメ ラーゼ活性が容易に測定されるようになって以 来, ほとんどの腫瘍細胞がテロメラ一ゼ活性を 有することがわかってきている。また，生殖細

防衛医科大学校第 2 外科

* 同微生物学教室

** 東海大学医学部健診センター
胞や幹細胞 ${ }^{3)}$ な゙一部の細胞を除いて正常細胞は テロメラーゼ活性を持なないことが示されてい る.このため腫瘍マーカーとしてテロメラ一ゼ 活性の役割が期待されてきている(4) 10).

肺癌の確定診断のためには組織診及び細胞診 が必須であり, 肺癌細胞が採取される必要があ る.しかし, 病理診断は形態学的な方法であり, 細胞数, 細胞の変性, 保存 - 固定の状態, 病理 医の熟練度, 経験, 能力によって診断が異なっ てくるという問題点がある.これに対しテロメ ラーゼ活性は生化学的に検出されるため, 客観 的評価が可能であるという利点を有する.

今回, 我々は気管支洗浄液のテロメラ一ゼ活 性を測定し, 肺癌の補助診断法としての有用性 
Table 1. Patient characteristics.

\begin{tabular}{|c|c|c|c|c|c|c|}
\hline & No. & Age & Sex & $\begin{array}{c}\text { Telomerase* } \\
\text { activity }\end{array}$ & $\begin{array}{c}\text { Cytology } \\
\text { (class) }\end{array}$ & Diagnosis/symptom \\
\hline \multirow{15}{*}{$\begin{array}{l}\text { Non-lung cancer } \\
\quad(\text { Control })\end{array}$} & 1 & 75 & $\mathrm{~F}$ & $\mathrm{~N}$ & II & Bronchogenic cyst \\
\hline & 2 & 74 & $\mathrm{~F}$ & $\mathrm{~N}$ & II & Lung abscess \\
\hline & 3 & 73 & M & $\mathrm{N}$ & II & Postoperatively lung cancer \\
\hline & 4 & 64 & M & $\mathrm{P}$ & II & Abnormal shadow \\
\hline & 5 & 45 & $\mathrm{~F}$ & $\mathrm{P}$ & II & Abnormal shadow \\
\hline & 6 & 54 & M & $\mathrm{P}$ & II & Mediastinal tumor \\
\hline & 7 & 65 & $\mathrm{M}$ & $\mathrm{N}$ & II & Esophageal cancer \\
\hline & 8 & 82 & M & $\mathrm{N}$ & II & Esophageal cancer \\
\hline & 9 & 61 & $\mathrm{M}$ & $\mathrm{N}$ & II & Esophageal cancer \\
\hline & 10 & 65 & M & $\mathrm{N}$ & II & Hemosputum \\
\hline & 11 & 65 & M & $\mathrm{P}$ & II & Hemosputum \\
\hline & 12 & 63 & $\mathrm{M}$ & $\mathrm{N}$ & II & Hemosputum \\
\hline & 13 & 72 & $\mathrm{~F}$ & $\mathrm{~N}$ & II & Thyroid tumor \\
\hline & 14 & 66 & $\mathrm{~F}$ & $\mathrm{~N}$ & II & Pneumonia \\
\hline & 15 & 62 & $\mathrm{~F}$ & $\mathrm{~N}$ & II & Pneumonia \\
\hline \multirow[t]{33}{*}{ Lung cancer } & 1 & 73 & $\mathrm{M}$ & $\mathrm{P}$ & II & Adenocarcinoma \\
\hline & 2 & 59 & $\mathrm{M}$ & $\mathrm{P}$ & II & Adenocarcinoma \\
\hline & 3 & 59 & $\mathrm{~F}$ & $\mathrm{~N}$ & II & Adenocarcinoma \\
\hline & 4 & 76 & $\mathrm{~F}$ & $\mathrm{~N}$ & II & Adenocarcinoma \\
\hline & 5 & 42 & $\mathrm{~F}$ & $\mathrm{~N}$ & III & Adenocarcinoma \\
\hline & 6 & 65 & $\mathrm{M}$ & $\mathrm{P}$ & III & Adenocarcinoma \\
\hline & 7 & 62 & $\mathrm{M}$ & $\mathrm{P}$ & IV & Adenocarcinoma \\
\hline & 8 & 70 & $\mathrm{M}$ & $\mathrm{P}$ & IV & Adenocarcinoma \\
\hline & 9 & 73 & $\mathrm{M}$ & $\mathrm{P}$ & $\mathrm{V}$ & Adenocarcinoma \\
\hline & 10 & 71 & $\mathrm{M}$ & $\mathrm{P}$ & $\mathrm{V}$ & Adenocarcinoma \\
\hline & 11 & 68 & $\mathrm{M}$ & $\mathrm{P}$ & $\mathrm{V}$ & Adenocarcinoma \\
\hline & 12 & 64 & $\mathrm{M}$ & $\mathrm{P}$ & $\mathrm{V}$ & Adenocarcinoma \\
\hline & 13 & 71 & $\mathrm{M}$ & $\mathrm{P}$ & $\mathrm{V}$ & Adenocarcinoma \\
\hline & 14 & 67 & $\mathrm{M}$ & $\mathrm{P}$ & $\mathrm{V}$ & Adenocarcinoma \\
\hline & 15 & 59 & $\mathrm{~F}$ & $\mathrm{P}$ & $\mathrm{V}$ & Adenocarcinoma \\
\hline & 16 & 81 & $\mathrm{~F}$ & $\mathrm{P}$ & $\mathrm{V}$ & Adenocarcinoma \\
\hline & 17 & 71 & $\mathrm{M}$ & $\mathrm{P}$ & II & Large cell carcinoma \\
\hline & 18 & 43 & $\mathrm{M}$ & $\mathrm{N}$ & II & Large cell carcinoma \\
\hline & 19 & 73 & $\mathrm{M}$ & $\mathrm{P}$ & II & Small cell carcinoma \\
\hline & 20 & 52 & $\mathrm{M}$ & $\mathrm{N}$ & III & Small cell carcinoma \\
\hline & 21 & 71 & $\mathrm{M}$ & $\mathrm{P}$ & IV & Small cell carcinoma \\
\hline & 22 & 67 & $\mathrm{M}$ & $\mathrm{N}$ & $\mathrm{V}$ & Small cell carcinoma \\
\hline & 23 & 53 & $\mathrm{~F}$ & $\mathrm{P}$ & $\mathrm{V}$ & Small cell carcinoma \\
\hline & 24 & 59 & $\mathrm{M}$ & $\mathrm{P}$ & $\mathrm{V}$ & Small cell carcinoma \\
\hline & 25 & 59 & M & $\mathrm{P}$ & $\mathrm{V}$ & Squamous cell carcinoma \\
\hline & 26 & 46 & $\mathrm{M}$ & $\mathrm{N}$ & $\mathrm{V}$ & Squamous cell carcinoma \\
\hline & 27 & 70 & $\mathrm{M}$ & $\mathrm{P}$ & $\mathrm{V}$ & Squamous cell carcinoma \\
\hline & 28 & 62 & M & $\mathrm{P}$ & $\mathrm{V}$ & Squamous cell carcinoma \\
\hline & 29 & 74 & $\mathrm{M}$ & $\mathrm{P}$ & $\mathrm{V}$ & Squamous cell carcinoma \\
\hline & 30 & 76 & $\mathrm{M}$ & $\mathrm{P}$ & $\mathrm{V}$ & Squamous cell carcinoma \\
\hline & 31 & 73 & M & $\mathrm{P}$ & $\mathrm{V}$ & Squamous cell carcinoma \\
\hline & 32 & 69 & $\mathrm{M}$ & $\mathrm{P}$ & $\mathrm{V}$ & Squamous cell carcinoma \\
\hline & 33 & 72 & M & $\mathrm{P}$ & $\mathrm{V}$ & Squamous cell carcinoma \\
\hline
\end{tabular}


について検討した。

\section{対 象}

1996年 8 月から 1997年 5 月までに当科で気管 支鏡施行時に気管支洗浄液を採取し, 検索可能 であった肺癌 33 症例と非肺癌 15 症例を対象とし た(Table 1)。肺癌の組織型は扁平上皮癌 9 例, 腺癌 16 例, 大細胞癌 2 例, 小細胞癌 6 例であっ た。

\section{方 法}

気管支洗浄液は, 経気管支肺生検後に生理食 塩水 $10 \sim 20 \mathrm{ml}$ 用いて採取し, その半量で細胞 診検査を行い, 残りの半量を用いてテロメラー ゼ活性を測定した。

テロメラーゼ活性測定法( TRAP変法 ${ }^{11)}$ )

CHAPS細胞抽出液の調整: 採取した検体を 4 ${ }^{\circ} \mathrm{C}$ に保ち, hypotonic lysisにより赤血球を除去 した後PBS (一)で洗浄し, CHAPS溶解液 $(10 \mathrm{mM}$ tris- $\mathrm{HCl}(\mathrm{pH} 7.5), \quad 1 \mathrm{mM} \quad \mathrm{MgCl}_{2} \quad 1 \mathrm{mM}$ EGTA, $0.1 \mathrm{mM}$ PMSF, $5 \mathrm{mM} \beta-\mathrm{ME}, 0.5 \%$ CHAPS, $10 \%$ glycerol)を加之た. 水上で30分 incubateした後15,000rpmで20分間遠心し上清 をcell lysateとした.蛋白濃度はBio-Rad Protein Assay Kitを用いて測定し, cell lysate 0.5 $\mu \mathrm{g}$ 夕 ンパク相当量についてテロメラーゼ活性を測定 した。

non-RI TRAP : Oncor社Trapeze telomerase detection Kit及び5’末端をジゴキシゲニン標識 したTS primerを用いることにより，RIを使用 せずにテロメラーゼ活性を測定した。

1) Telomerase反応およびPCR : $0.4 \mathrm{ml} \mathrm{PCR}$ チューブにRP, K1, TSK1 primer Mixを $1 \mu \mathrm{l}$

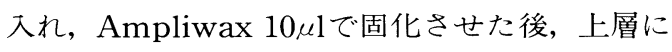
$50 \mu 1$ TRAP反応液 (20mM Tris- $\mathrm{HCl}$ ( pH8.3), $1.5 \mathrm{mM} \mathrm{MgCl}_{2}, 63 \mathrm{mM} \mathrm{KCl}, 0.005 \%$ Tween20, $1 \mathrm{mM}$ EGTA, $50 \mu \mathrm{M}$ dNTP, TS primer $0.1 \mu \mathrm{g}$, T4 gene 32 protein $1 \mu \mathrm{g}$, BSA $0.1 \mathrm{mg} /$ $\mathrm{ml}$, Taq polymerase $2 \mathrm{U}, \mathrm{CHAPS}$ 細胞抽出液 $0.5 \mu \mathrm{g})$ を加之た. $23^{\circ} \mathrm{C} て ゙ 10$ 分間テロメア配列の 伸長反応を行った後, PCRにより伸長したテロ メア配列を増幅した。 PCRは, $94^{\circ} \mathrm{C} 30$ 秒， $50^{\circ} \mathrm{C}$
30 秒, $72^{\circ} \mathrm{C} 90$ 秒を 31 サイクル行った.

2 ) Signal detection: PCR産物 $5 \mu \mathrm{l}$ 10\% Native-PAGEにより分離した後, DNAを十イロ ン膜(イモビロンS)に転写した。紫外線 $3,300 \mu \mathrm{J} /$ $\mathrm{cm}^{2}$ でDNAをナイロン膜にUVクロスリンクし, DIG luminescent detection kit (Boehringer Mannheim社)を用いてシグナルを検出した. TRAP生成物とinternal control band (36bp : TSK1)の増幅は半競合的なので, 50 塩基以上の 6 塩基ずつのladderの濃さとこれを比較するこ とによりテロメラーゼ活性の指標とした。

\section{結 果}

（）non-RI TRAP法によるテロメラーゼ活性の測 定感度の検定

non-RI TRAP法によるテロメラーゼ活性の測 定感度をみるため, $10^{2}$ 個〜 $10^{6}$ 個の腫瘍細胞株 (EL-4, HL-60)をCHAPS溶解液200 $\mu 1$ に加之て cell lysateを作成しその $2 \mu 1$ 用いてTRAP反応 を行った.この方法では, 細胞数 $10^{2}$ 個から開始 した実験でもテロメラーーゼ活性の検出が可能で あり, 理論的には細胞 1 個相当量 $\left(10^{2} / 200 \mu 1\right.$ 中の $2 \mu \mathrm{l})$ からの検出が可能であった(Fig. 1).

次にfibroblast(テロメラーゼ活性陰性株)にEL4を $1 ： 10 〜 1 ： 10^{5}$ 個までの種々の割合で混合し 総数が $10^{6}$ 個となるようにしたサンプルから cell lysateを作成し，その0.5 $\mu \mathrm{g}$ を用いてテロメラー ゼ活性を測定した.その結果 $1: 10^{4}$ (fibroblast $10^{4}$ 個に対LEL-4細胞 1 個の割合)までテロメラ 一ゼ活性の検出が可能であった(Fig. 2).

以上の結果から, 少なくとも細胞総数が $10^{6}$ 個 あった場合, 細胞 $10^{4}$ 個中に 1 個の確率で存在す るテロメラーゼ活性陽性細胞 (腫瘍細胞)を検出 することが可能であることが分かった。したが って, 通常の方法で採取した $5 \sim 10 \mathrm{ml}$ の気管支 洗浄液中の細胞から充分にテロメラーゼ活性を 検出し得ると考えられたので，以下のように患 者の気管支洗浄液中のテロメラーゼ活性検出を 試みた。

（2）気管支洗浄液中細胞のテロメラーゼ活性

気管支洗浄液(肺癌症例33検体, 対照群として 非肺癌症例15検体)のテロメラーゼ活性を測定し， 
Fig. 1.

Sensitivity of the non-RI TRAP method.

CHAPS extract $(200 \mu 1)$ was made from $10^{2}$ to $10^{6}$ tumor cells (EL-4 and HL-60) and telomerase activity (in 2 $\mu l$ CHAPS extract) was measured.

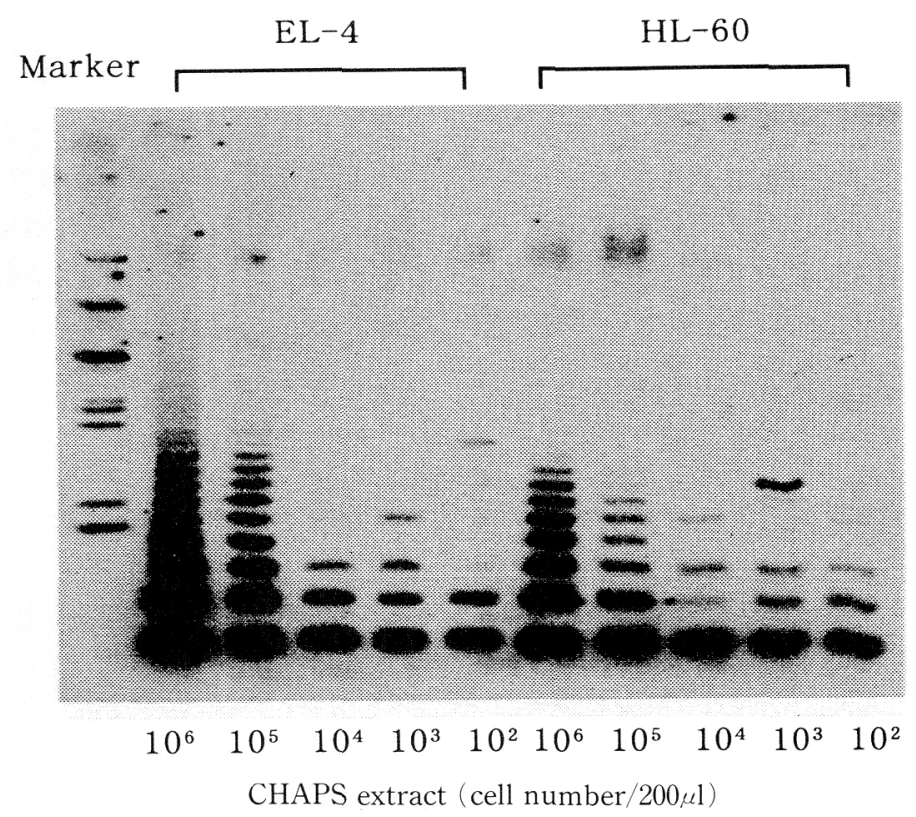

Fig. 2.

Effect of EL-4 : fibroblast ratio on the sensitivity of telomerase activity.

EL -4 cells and fibroblasts were mixed in variable ratio (from 1 : $\left.10 \sim 1: 10^{5}\right)$ and CHAPS extracts were prepared. Telomerase activity of each extract was compared in the same PAGE gel.

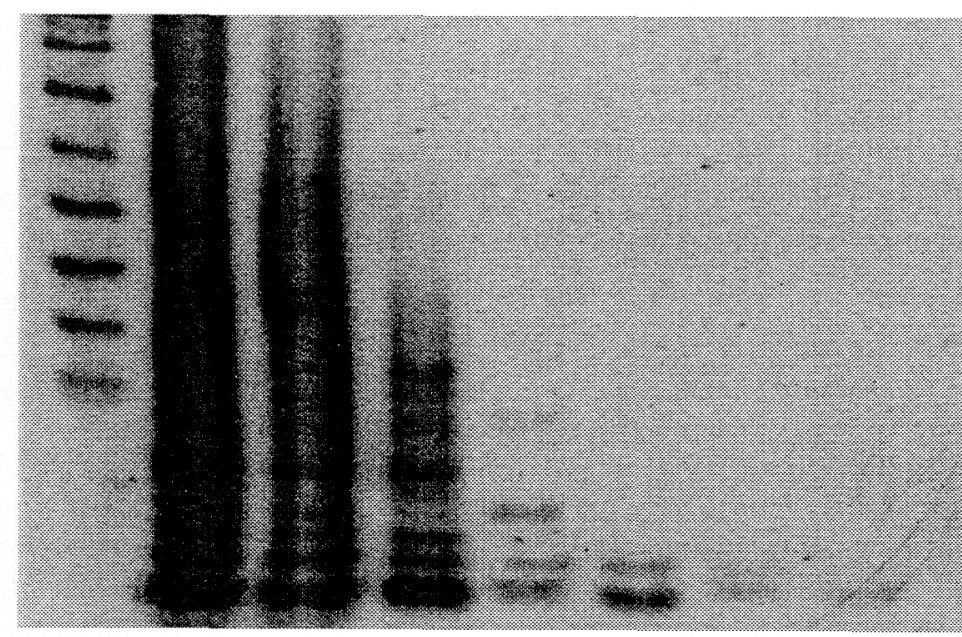

\section{Marker $\begin{array}{lllll}\text { EL-4 } \\ \text { only }\end{array} \quad 1: 10 \quad 1: 10^{2} \quad 1: 10^{3} \quad 1: 10^{4} \quad 1: 10^{5} \begin{gathered}\text { Fibroblast } \\ \text { only }\end{gathered}$}

EL-4 : fibroblast ratio

洗浄液の細胞診と比較した.Fig. 3は肺癌症例と 非肺癌症例の細胞診とテロメラーゼ活性につい ての電気泳動の一例を示す。肺癌症例では非癌 症例に比べ気管支洗浄液中のテロメラーゼ活性 は高い陽性率を示し，細胞診とほぼ同等の陽性 率78.8\%(26/33)であった。それに対し非肺癌症 例におけるテロメラーゼ活性陽性率は $26.7 \%$ ( 4 /
15)であった(Fig. 4).

細胞診所見とテロメラーゼ活性陽性率の相関 についてみた場合(Fig. 5), class II で36.4\%, class III で33.3\%, class IV, V で91.3\%の陽性 率を示し, 細胞診のclassが高いものほどテロメ ラーゼ活性の陽性率も高率であった $(\mathrm{p}=0.0001$ : Spearman). 次に細胞診class II の症例のテロ 
Fig. 3.

Representative pattern of telomerase activity in the clinical cases. CHAPS extracts were prepared from the bronchial lavage (lung cancer 33 cases and non-lung cancer 15 cases) and telomerase activity was determined by TRAP assay.

Fig. 4.

Cytology and telomerase activity of lung cancer and non-lung cancer cases.

The proportion of positive telomerase activity and rate of class IV or $\mathrm{V}$ by cytological examination are displayed in the same panel. Actual numbers of positive cases vs total cases are indicated on the top of each column.

Fig. 5.

Relationship between telomerase activity and cytological classification of the bronchial lavage specimens.

The telomerase-positive rate increases as the degree of cytological abnormality increases ( $\mathrm{p}$ = 0.0001:Spearman rank correlation).

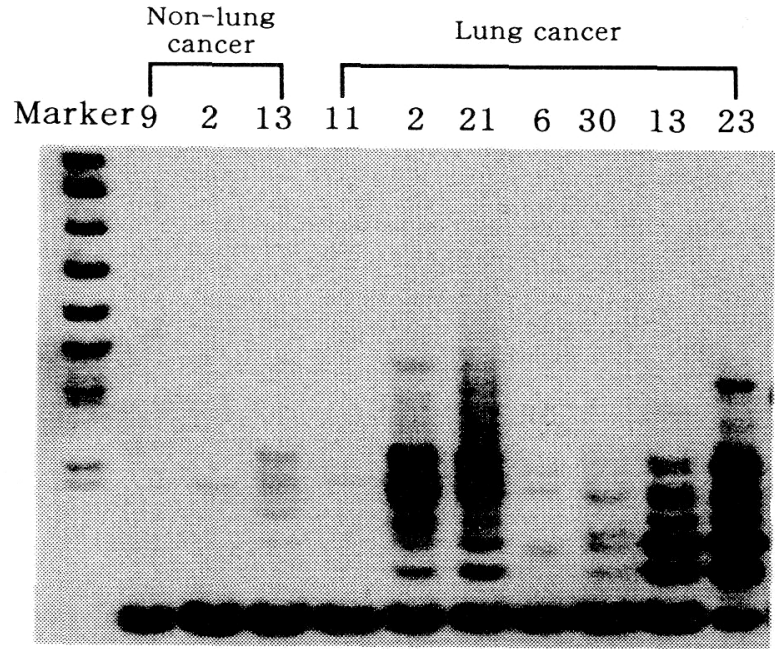

\section{Telomerase \\ activity --+-+++++

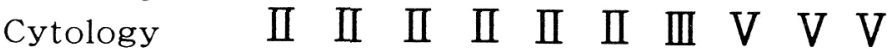
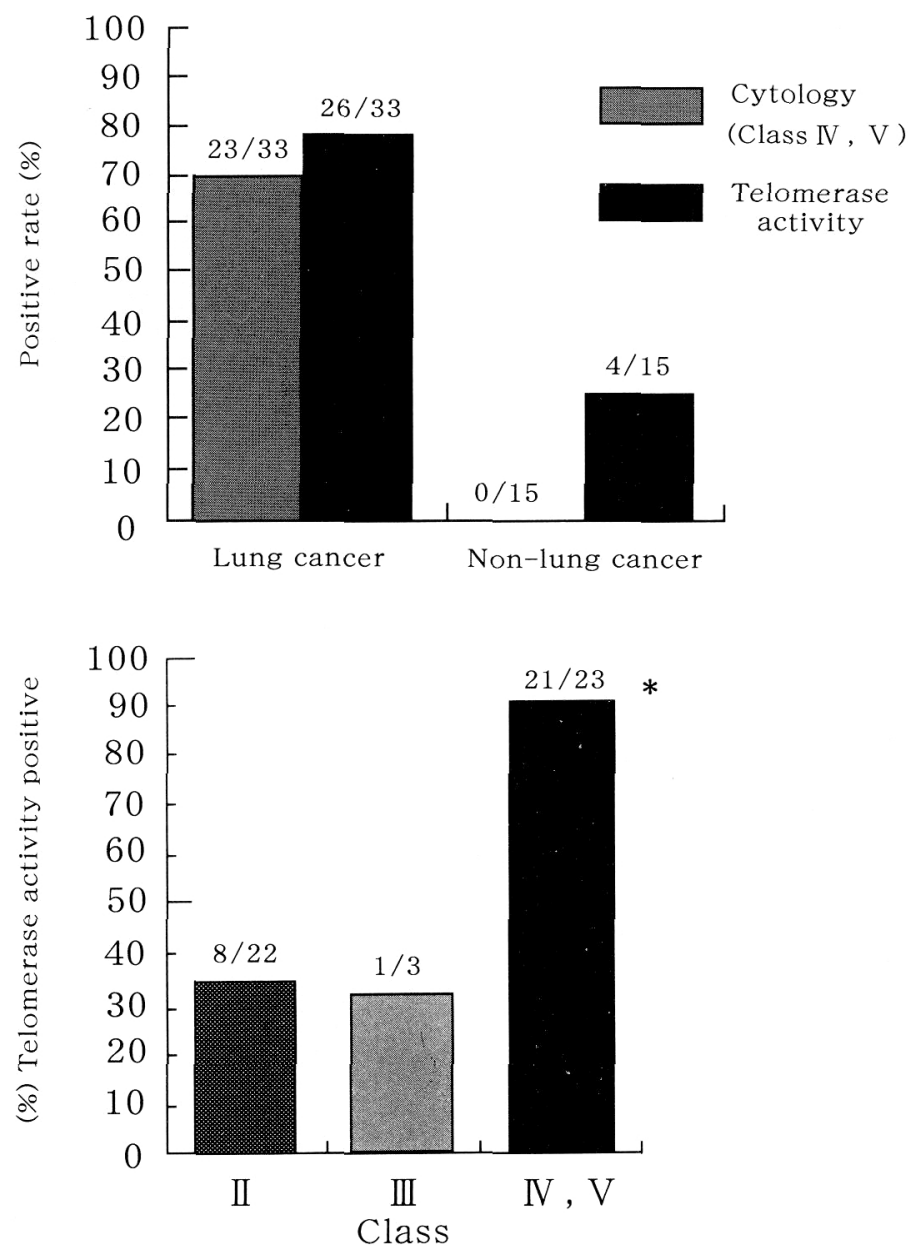
Fig. 6.

Telomerase activity of lung cancer and non-lung cancer in class II cases.

Lung cancers tend to show a higher telomerase positive rate, though statistical significance was not observed $(* \mathrm{p}=0.13)$.
Fig. 7 .

Relationship between histopathological diagnosis and telomerase positive rate.

The proportion of positive telomerase activity and the rate of class $\mathrm{V}$ or $\mathrm{V}$ on cytological examination are displayed in the same panel.

Actual numbers of positive cases vs total cases are indicated on the top of each column, according to the histopathological diagnosis.
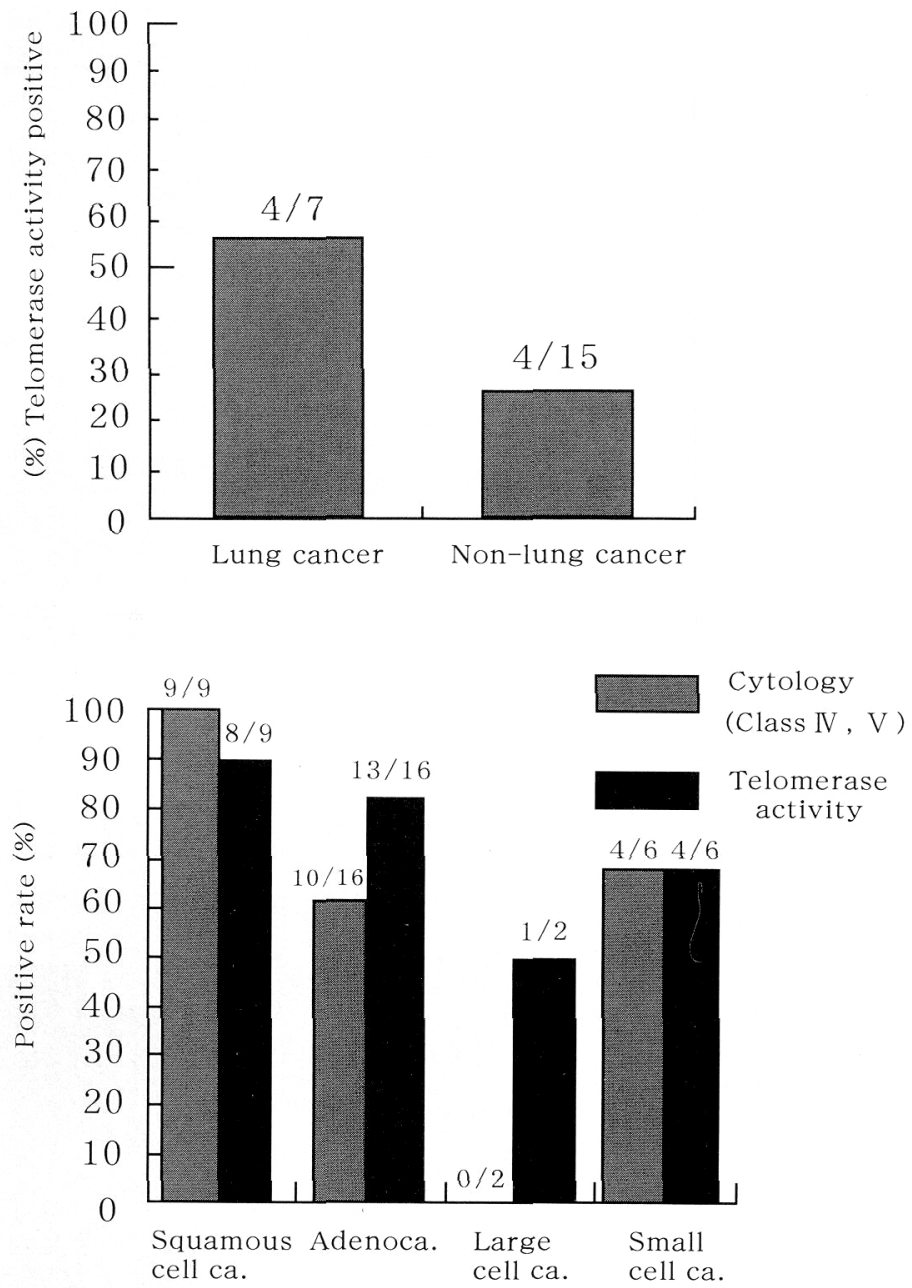

メラ一ゼ活性の陽性率を肺癌症例と非肺癌症例 に分けてみた場合(Fig. 6), 肺癌のうちテロメラ 一ゼ活性陽性例は $57.1 \%(4 / 7)$, 非肺癌で26.7

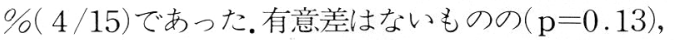
肺癌症例でテロメラーゼ活性が高い傾向にあっ た。

組織型別のテロメラーゼ活性は，扁平上皮癌 $88.9 \%$, 腺癌 $81.3 \%$, 大細胞癌 $50 \%$, 小細胞癌 $66.7 \%$ で，いずれの組織型でも高い陽性率を示 し, 組織型による差は認められなかった(Fig.7)。

\section{考 察}

TRAP法が開発されて以来, ほとんどの悪性 腫瘍でテロメラーゼ活性が陽性を示すことが明
らかになっている。肺癌組織については，我々 の施設において1991年 7 月から1996年 4 月の間 に切除した肺癌組織のテロメラーゼ活性陽性率 は $87.3 \%$ (腺癌 $82.5 \%$, 扁平上皮癌 $100 \%$ ) と高 い值を示し ${ }^{12)}$, Hiyama $^{13)}$ らの報告( 小細胞癌 100 $\%$, 非小細胞癌 $78.4 \%$ ) とほぼ同様である。テロ メラーゼ活性は悪性腫瘍に特異的に発現し, 非 癌組織ではほとんど認められないという特質が あり，診断における有力な新しい腫瘍マーカー として期待されている。一方, 覀性腫瘍の確定 診断のためには組織診あるいは細胞診が必要不 可欠である。肺癌患者では特に確定診断や治療 方針決定のために気管支鏡検査が必須である。 気管支鏡では腫瘍の局在等の条件により必ずし 
も組織診断が得られるとは限らず，気管支洗浄 液等による細胞診で診断が得られることも多い. しかし, 肺癌患者の気管支洗浄液でも異型細胞 が認められずにclass II と判定される場合や, 異 型細胞の数や変性のためにclass III と判定せざる えないことは日常の診療の中でよく経験される ことである。今回の我々の検討では, 肺癌症例 の気管支洗浄液に扔けるテロメラーゼ活性の陽 性率は比較的高率であり, 細胞診の結果と相関 していた。また, 気管支洗浄液がclass II を示し た肺癌のテロメラーゼ活性の陽性率は非肺癌よ りも高かった。この結果から肺癌のスクリーニ ング検查として細胞診のみの場合と細胞診とテ ロメラーゼ活性を組み合わせた場合を比較する と, 特異度は 1 から 0.73 に低下するものの感度 は0.70から 0.85 となり, 画像診断, 血清学的検 查等で肺癌が疑わしい症例では気管支洗浄液中 のテロメラーゼ活性は補助診断として利用でき る可能性が示唆された。

脳脊䯣圧充進症状がみられた患者で脳脊髄液 の細胞診はclass III， class IIIbであったが，テ ロメラーゼ活性は強陽性であり, 最終的に肺癌 による癌性髄膜炎と診断された症例を経験して いる。

末梢血液中からテロメラーゼ活性を検出した

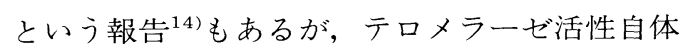
は個々の細胞から検出されるため組織あるいは 細胞の直接採取が必要である。このような点か
ら気管支 ${ }^{15), 16)}$, 腹腔 ${ }^{17)}$, 膀胱 ${ }^{18)}$, 腸管 ${ }^{4)}$ 等の洗浄 液や, 喀痰, 胸水 ${ }^{17)}$, 尿 ${ }^{5)}$, 蓃液 ${ }^{19), 20)}$ 等における テロメラーゼ活性の測定は診断上有用であると 考えられる。

今回の測定では非肺癌症例でも $26.7 \%$ はテロ メラーゼ活性が陽性を示している。活性化した リンパ球は微弱であるがテロメラーゼ活性を示 すことが知られており ${ }^{3)}$, 炎症性疾患患者ではそ の解勫に特に注意を要すると考えられた。テロ メラーゼ活性がリンパ球由来であるかどうかを 区別する必要性がある時には, TBLBを行う前の 洗浄液のテロメラーゼ活性を同時に測定し背景 の活性と比較して判断するか, in situアッセ

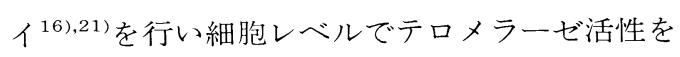
測定することが必要であろう。

今回, 我々が用いたnon-RI TRAP法は, TRAP 原法と同様の感度であり, $10^{4}$ 個の非腫瘍細胞中 にたった 1 個の腫瘍細胞を検出可能であった. 本法はRIを用いないため通常の研究室で広く簡 便に行うことができ，実際の癌診断に用いる場 合には有用な方法であると考えられる。

\section{結 語}

（1）気管支洗浄液中のテロメラーゼ活性は肺癌 の補助診断として有用である。

（2）我々が用いたnon-RI TRAP法はRIを用い た原法と同等の感度であり, 通常の研究室レべ ルでのテロメラーゼ測定に有用である。

\section{文 献}

1) Greider $\mathrm{CW}$ : Telomere length regulation. Annu Revi Biochem 65 : 337-365, 1996.

2) Kim NW, Piatyszek MA, Prowse KR, et al : Specific association of human telomerase activity with immortal cells and cancer. Science 266 : 2011-2015, 1994.

3) Hiyama K, Hirai Y, Kyoizumi S, et al : Activation of telomerase in human lymphocytes and hematopoietic progenitor cells. J Immunol 155 : 3711-3715, 1995.

4) Yoshida K, Sugino T, Goodison S, et al : Detection of telomerase activity in exfoliated cancer cells in colonic luminal washings and its related clinical implication. Br J Cancer 75 : 548-553, 1997.

5) Yoshida K, Sugino T, Tahara H, et al : Telomerase activity in bladder carcinoma and its implication for noninvasive diagnosis by detection of exfoliated cancer cells in urine. Cancer 79 : 362-369, 1997.

6) Iwao T, Hiyama E, Yokoyama $T$, et al : Telomerase activity for the preoperative diagnosis of pancreatic cancer. J Natl Cancer Inst $89:$ 1621-1623, 1997. 
7) Umbricht CB, Saji M, Westra WH, et al : Telomerase activity: a marker to distinguish follicular thyroid adenoma from carcinoma. Cancer Res 57 : 2144-2147, 1997.

8) Shay JW, Gazdar AF : Telomerase in the early detection of cancer. J Clin Pathol 50 : 106-109, 1997.

9）檜山桂子, 檜山英三, 石岡伸一, 他 : 肺癌 診断 と治療の進歩 肺癌診断と治療の新たなターゲッ トテロメアとテロメラーゼ.日内会誌 $86: 95-$ 99, 1997.

10）大村泰之, 佐伯俊昭, 高嶋成光, 他 : 甲状腺腫 瘍の細胞診材料におけるテロメラーゼ活性 細胞 診診断とテロメラーゼ活性の比較. 日外会誌 $98: 113,1997$.

11）出口博之, 竹村俊哉, 奥村 敦, 他: アイソト ープを用いないテロメラーゼ活性検出法(TRAP 法)について。防衛医大誌 $21: 199-203,1996$.

12）出口博之, 四八宮成祥, 佐藤光春, 他: 肺癌細 胞におけるテロメラーゼ活性の測定ジゴキシゲ ニン標識プライマーを用いたTRAP法による検 出の試み. 肺癌 $36: 560,1996$.

13) Hiyama K, Hiyama E, Ishioka S, et al : Telomerase activity in small-cell and nonsmall-cell lung cancers. J Natl Cancer Inst 87 : 895-902, 1995.

14）小柳和夫, 小澤壯治, 安藤暢敏, 他: 食道扁平 上皮癌における末梢血液テロメラーゼ活性の検
討. 日外会誌 $98: 218,1997$.

15）礒部 威, 檜山桂子, 宮崎 満, 他：肺癌診断 における細胞診検体中のテロメラーゼ活性測定 の意義. 肺癌 $36: 499,1996$.

16) Yahata N, Ohyashiki K, Ohyashiki JH, et al : Telomerase activity in lung caner cells obtained from bronchial washings. J Natl Cancer Inst $90: 684-690,1998$.

17) 吉見直已, 井野夏子, 高橋京子, 他 : 細胞診へ のフィードバックを目ざす新しい手法 体腔液 細胞診材料におけるテロメラーゼ活性の検討. 日臨細胞会誌 $36: 76-80,1997$.

18）鈴木謙一, 星宣次, 高橋とし子, 他 : 膀胱癌症 例に扔ける膀胱洗浄液テロメラーゼ活性の測定. 日泌会誌 88, 163，1997.

19）水元一博, 末原伸泰, 新山秀昭, 他: 膵液中テ ロメラーゼ活性半定量による膵癌の診断. 日外 会誌 $98: 367,1997$.

20) Hiyama E, Kodama T, Shinbara K, et al : Telomerase activity is detected in pancreatic cancer but not in benign tumors. Cancer Res 57 : 326-331, 1997.

21) Ohyashiki K, Ohyashiki JH, Nishimaki J, et al : Cytological detection of telomerase activity using an in situ telomeric repeat amplification protocol assay. Cancer Res $57: 2100-2103,1997$. 


\title{
The Utility of Telomerase Activity in Bronchial Lavage for the Diagnosis of Lung Cancer
}

\author{
Hiroyuki Deguchi, Nariyoshi Shinomiya*, Yuichi Ozeki \\ Mitsuharu Sato, Motohisa Kuwahara, Shyuji Haraguchi \\ Toshiro Ogata** and Susumu Tanaka
}

\author{
Department of Surgery II and *Microbiology, \\ National Defense Medical College \\ ${ }^{* *}$ Health Examination Center, \\ School of Medicine, Tokai University
}

\begin{abstract}
To evaluate its utility as a supplemental diagnostic aid, we measured telomerase activity in bronchial lavage specimens of 33 lung cancer cases and 15 non-lung cancer cases by the non-RI TRAP method. Lung cancers showed a higher proportion of positive telomerase activity $(78.8 \%)$ than non-lung cancer cases $(26.7 \%)$. The proportion of positive telomerase activity in lung cancers by histological typing was squamous cell carcinoma $88.9 \%$, adenocarcinoma $81.3 \%$, large cell carcinoma $50 \%$, and small cell carcinoma $66.7 \%$, respectively. When divided by cytological appearance, the proportion of positive telomerase activity was class II $36.4 \%$, class III $33.3 \%$, class $\mathrm{V}$ and V $91.3 \%$, suggesting that the proportion of positive telomerase activity increases as the grade of cytologic abnormality rises (Spearman $: \mathrm{p}=0.0001$ ). Class II cases finally diagnosed as lung cancer showed a higher proportion of positive telomerase activity $(57.1 \%)$ than nonlung cancer cases $(26.7 \%)$. These results suggest that the measurement of telomerase activity in the cells of bronchial lavage fluid may be useful as a supplemental diagnostic aid for lung cancers, particularly in cases negative on cytological examination.
\end{abstract}

